Article

\title{
Lettuce (Lactuca sativa) handling features and coliform levels in markets of Maputo City
}

\author{
Edgar Cambaza ${ }^{1,2 *}$, Luís Gazeta ${ }^{3}$, Elda Anapakala ${ }^{3}$, Shigenobu Koseki ${ }^{1}$ \\ 1 Laboratory of Agricultural and Food Process Engineering, Graduate School of Agriculture, Hokkaido \\ University, Japan; koseki@bpe.agr.hokudai.ac.jp \\ 2 Department of Biological Sciences, Faculty of Sciences, Eduardo Mondlane University, Maputo, \\ Mozambique; accademus@protonmail.com \\ 3 National Laboratory of Water and Food Hygiene (LNHAA), Ministry of Health, Avenida F.P.L.M, n.147, \\ Maputo, Mozambique; luis.gazeta013@gmail.com \\ 4 National Institute of Health, Ministry of Health, Maputo, Mozambique; elda.muianga07@gmail.com \\ * Correspondence: accademus@protonmail.com; Tel.: +81 8028761106
}

\begin{abstract}
Markets from Maputo City have been reported to have poorly hygienic premises and sellers unaware of the safest food handling practices. This study aimed to analyze associations between some lettuce (Lactuca sativa) handling features and the levels of total, fecal coliforms and Escherichia coli. Cabbage was purchased in the 3 markets. Just before the acquisition, the researchers recorded the source of water used to wash it, if they were sold in booths or on the floor, if they were sold mixed with other products, and if the sellers were wearing gloves. The cabbage heads (42) were analyzed through the technique of multiple tubes to estimate the most probable number. Average levels were 14.43 MPN/g for total coliforms, $13.9 \mathrm{MPN} / \mathrm{g}$ for fecal coliforms and 12.02 MPN/g for E. coli. The highest levels of contamination seemed associated with the use of well water, the food sold on the floor, the lettuce sold together with other products and the lack of gloves. The mixture of products only showed a major impact on the level of E. coli $(p<0.001)$. Yet, all levels were within the satisfactory range, according to the guidelines from The International Commission on Microbiological Specifications for Foods (ICMSF).
\end{abstract}

Keywords: Lactuca sativa; handling; total coliforms; fecal coliforms; Escherichia coli; Maputo

\section{Introduction}

Lettuce (Lactuca sativa) is commonly sold in major markets of Maputo City. According to Sitoe [1], the familiar sector produces most of it as an important income source because it is highly profitable. It is produced mainly by $94 \%$ of the farmers in the so-called zonas verdes (green zones), urban areas with plenty of water available but not very fertile [2,3]. Thus, the farmers are compelled to use fertilizers, often manure or bio-solids [2]. Natural fertilizers may contain pathogens able to persist for weeks and sometimes months [4]. Furthermore, the water uses for irrigation might be contaminated because Muchimbane [5] said the sanitation is precarious and water from latrines might access the water table. These paths for microbial contamination pose a risk to public health, especially because lettuce is often eaten raw in salads. There are records of lettuce causing Escherichia coli O157:H7 infections [6].

So far, no study directly analyzed coliform contamination in food from markets in Maputo City, but some give an idea. Macaza [7] detected E. coli in $83 \%$ of ready-to-eat food from markets in Nampula City. The ingredients were not specified and it was another city but the study demonstrated that fecal microorganisms could survive the entire process of preparation and make into food. Alves [8] conducted interviews with sellers in three markets from Maputo City and found the great majority had little knowledge on food safety, not fulfilling satisfactory hygiene practices. Moreover, the food was not properly preserved, was exposed to dust, insects, and the number of sellers appeared to be increasing over time. Overall conditions were precarious, often without tap 
water, sinks or toilets. Thus, it is important to know at which extent this scenario affects the safety of the food from Maputo City markets.

This study aimed to evaluate the hygiene of lettuce handling in three major markets of Maputo City, in Mozambique, by analyzing the impact of some practices and conditions on the level of total, fecal coliforms and E. coli.

\section{Materials and Methods}

\subsection{Sampling}

Lettuce (L. sativa) samples were collected in three informal markets from Maputo City: Central (or Municipal), Xipamanine and Xiquelene. According to the Ministry of Environmental Coordination [9], the Central is a regulator market, created by the City Hall, larger and with a wider variety of products. It is expected to have the highest quality standards among the city markets. The other two are classified as neighborhood markets, created by groups of inhabitants from certain areas of the city, sometimes urban districts or neighborhoods. These markets are not expected to have the same quality standards or at least the level of enforcement because they are not managed by the City Hall.

The handling features were recorded just before and during the purchase. They included:

- The source of water used to wash the lettuce (tap or underground well);

- If the lettuce was sold in booths or on the floor (on a sheet of plastic or similar synthetic material, sometimes on a box or small table, never higher than $50 \mathrm{~cm}$ );

- If it was mixed or not with other vegetables, fruits or commodities;

- If the sellers used gloves or other sorts of protection preventing them from touching the lettuce.

Each seller provided one lettuce head and it was stored in an aseptic plastic bag at room temperature, always collected from 9 o'clock in the morning. The samples were 66, one-third from each market, apparently fresh, without spots or dark areas. The samples were taken from lots of 13 in one-week intervals, always alternating between the markets, until completing the target number (it took 5 weeks). The particular sellers were not repeated. They were tagged as collected, with information on the market from which they came from. The lettuce was taken directly from the markets to the laboratory for analysis. No sample took more than two hours from the collection to analysis, in the National Laboratory of Water and Food Hygiene (LNHAA-MISAU).

\subsection{Microbiological analysis}

Samples with incomplete data as described in section 2.1 were excluded from the analysis. The damaged parts of the lettuce were removed and $25 \mathrm{~g}$ of each lettuce head were crushed and homogenized in a Seward Stomacher blender. Then, samples were diluted in $225 \mathrm{ml}$ of $0.1 \%$ sterilized peptone water ( $\mathrm{pH}$ between 6.8 and 7 ), followed by serial dilutions down to $10^{-1}$. The technique of multiple tubes described by McCrady [10] was used to estimate the most probable number (MPN) of total, fecal (or thermotolerant) coliforms, and E. coli per gram of lettuce.

\subsection{Statistical analysis}

All statistical analysis was performed on IBM SPSS Statistics 20. The variables analyzed were the bacterial estimated number per gram of lettuce, markets and four handling features: washing water source (tap or well), lettuce disposition (booth or floor), if the lettuce had been mixed with other foods, and if it had been handled with gloves.

First, a cross table exhibited the frequency of each feature across the markets, compared, and a chi-square test $(a=0.05)$ showed the significance of their differences. It was followed by a comparison between the levels of the different groups of coliforms analyzed. After that, the statistical treatment was the same in all categories of bacteria. Then, the distribution of the most probable numbers was analyzed, and descriptive parameters such as mean, standard deviation, range and confidence interval were presented. Finally, the results per market were presented and 
compared through box plots and Kruskal-Wallis tests. A similar approach was taken for the handling features, but using Mann-Whitney tests instead.

\section{Results}

\subsection{Lettuce handling features}

The samples with incomplete information were excluded from the 66 originally collected. In the end, 42 were effectively analyzed, 14 from each market. In the end, 42 were effectively analyzed, 14 from each market. Handling features were registered (Table 1). It was possible to record the source of water the sellers used to wash the lettuce, how they disposed the food for sale, if they mixed it with other food during the sales and if they handled the lettuce with gloves.

Table 1. Lettuce handling features in three markets from Maputo City.

\begin{tabular}{|c|c|c|c|c|c|}
\hline \multirow{2}{*}{\multicolumn{2}{|c|}{ Handling features }} & \multicolumn{3}{|c|}{ Number of samples } & \multirow{2}{*}{$\begin{array}{c}\text { p-value } \\
\text { (chi-square, } \\
\alpha=0.05 \text { ) }\end{array}$} \\
\hline & & \multirow{2}{*}{$\frac{\text { Central }}{14}$} & \multirow{2}{*}{$\frac{\text { Xipamanine }}{13}$} & \multirow{2}{*}{$\frac{\text { Xiquelene }}{6}$} & \\
\hline Washing water & Tap & & & & \multirow{2}{*}{0.000} \\
\hline source & Well & 0 & 1 & 8 & \\
\hline \multirow{2}{*}{ Disposition } & Booth & 14 & 0 & 0 & \multirow{2}{*}{0.000} \\
\hline & Floor & 0 & 14 & 14 & \\
\hline \multirow{2}{*}{ Mixed } & No & 4 & 6 & 4 & \multirow{2}{*}{0.651} \\
\hline & Yes & 10 & 8 & 10 & \\
\hline \multirow{2}{*}{$\begin{array}{c}\text { Handling with } \\
\text { gloves }\end{array}$} & No & 9 & 14 & 14 & \multirow{2}{*}{0.003} \\
\hline & Yes & 5 & 0 & 0 & \\
\hline
\end{tabular}

Some practices were used in all markets while others only in one or another market. The central market was the using exclusively tap water, Xipamanine had all but one using tap, and Xiquelene used well water in the majority of the samples (8 out of 14). All samples from the Central market were sold in booths, while the others were displayed on the floor. The differences were not significant $(p=0.651)$ between the samples from different markets regarding the mixture with other foods. Gloves were only used in the central market, and only 5 out of 14 samples were handled with protected hands.

\subsection{Coliform contamination}

\subsubsection{Overview}

E. coli is a fecal coliform, and fecal coliforms are a subgroup within the total coliforms. So, how much of the total were fecal, and how much were E. coli? The Figure 1 displays the distributions of coliform levels, side-by-side. 


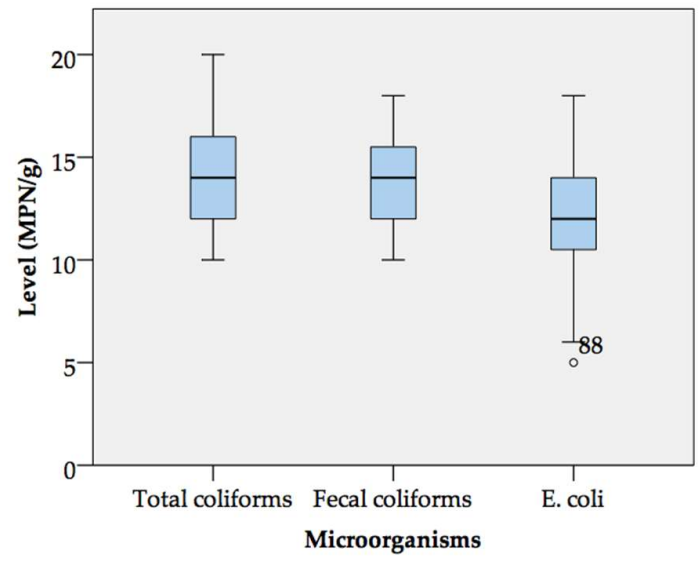

(a)

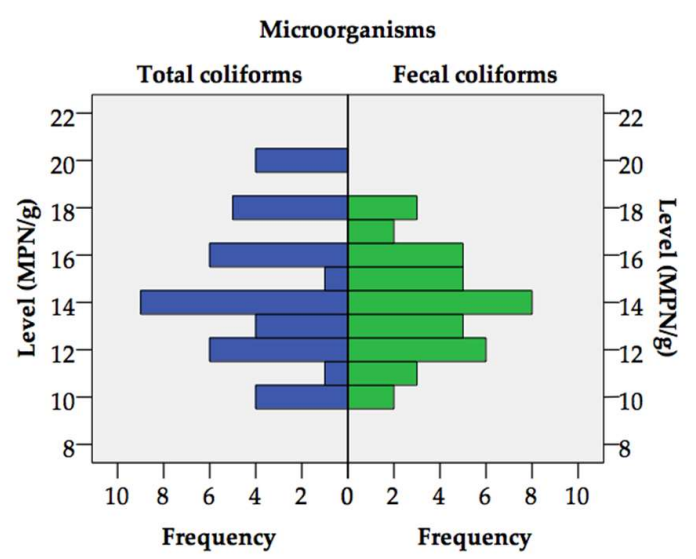

(b)

Figure 1. Comparison between the distributions of coliform levels: (a) all considered in the current studies; (b) only total and fecal coliforms.

All presented two tailed normal distributions, with the medians falling within the range 10-15 MPN/g. However, the distributions are significantly different, according to a related-samples Friedman's two-way analysis of variance by ranks $(p<0.001)$. Yet, Figure 1a shows a noticeable similarity between the sizes of the second and third interquartile intervals of total and fecal coliforms, suggesting considerable proximity between them. Indeed, this proximity was confirmed by a Wilcoxon signed rank test for related samples $(p=0.371)$. Figure $1 b$ shows their similar median (14 MPN/g) and abundance of mostly the same set of values. These observations point to the idea that the coliforms found in the sample were at great extent fecal but not necessarily E. coli.

\subsubsection{Total coliforms}

The total coliforms were quantified for all samples (Figure 2). The distribution was normal ( $\mathrm{p}$-value $=142$ ), and the levels of contamination ranged from $10 \mathrm{MPN} / \mathrm{g}$ to $20 \mathrm{MPN} / \mathrm{g}$ but $95 \%$ of the samples were within $13.53 \mathrm{MPN} / \mathrm{g}$ to $15.34 \mathrm{MPN} / \mathrm{g}$. The average was $14.43 \mathrm{MPN} / \mathrm{g}$. According to the observations, no sample was free of coliforms, independently of the treatment.

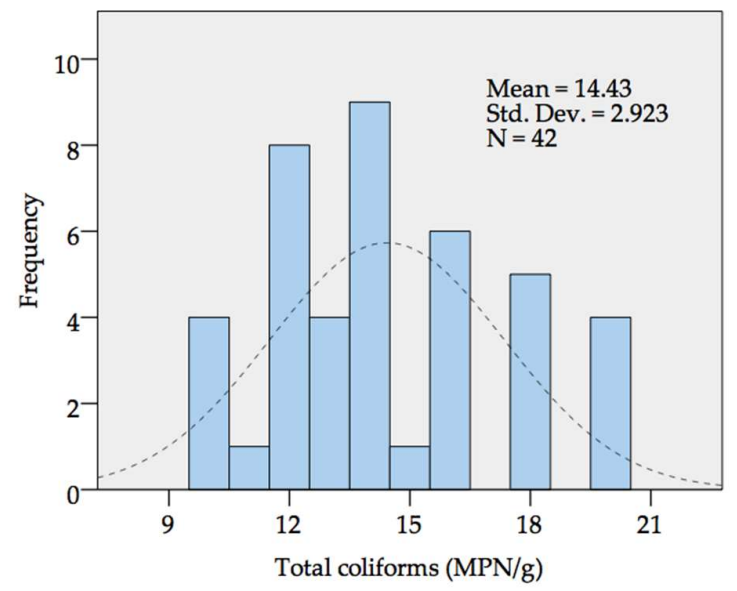

Figure 2. Levels of total coliforms detected in lettuce from Maputo City markets.

Samples from Xiquelene were more heavily contaminated in relation to the others (Figure 3a), with a mean load of $17.57 \pm 2.102 \mathrm{MPN} / \mathrm{g}$ against $13 \pm 1.84 \mathrm{MPN} / \mathrm{g}$ in the Central market and $12.71 \pm$ $1.773 \mathrm{MPN} / \mathrm{g}$ in Xipamanine. Xiquelene's samples presented a negative kurtosis (-0.294) and 
one-tailed distribution, meaning that even between this sample subset there is predominance of the lettuces with the heaviest total coliform loads.

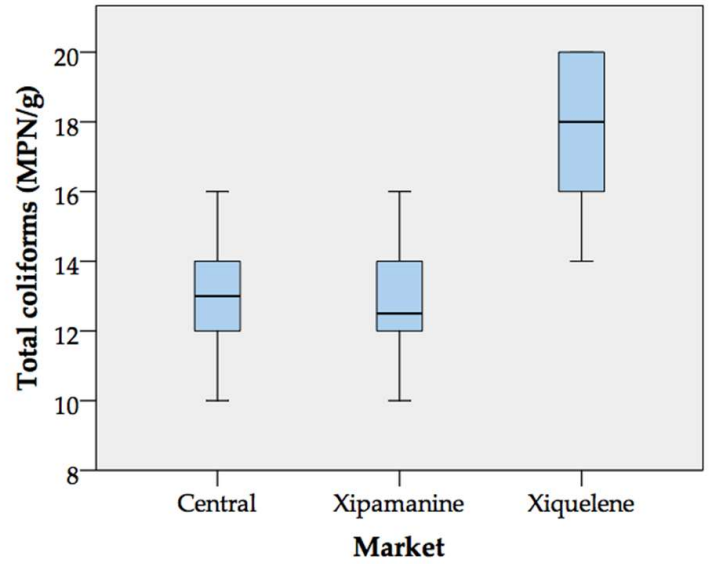

(a)

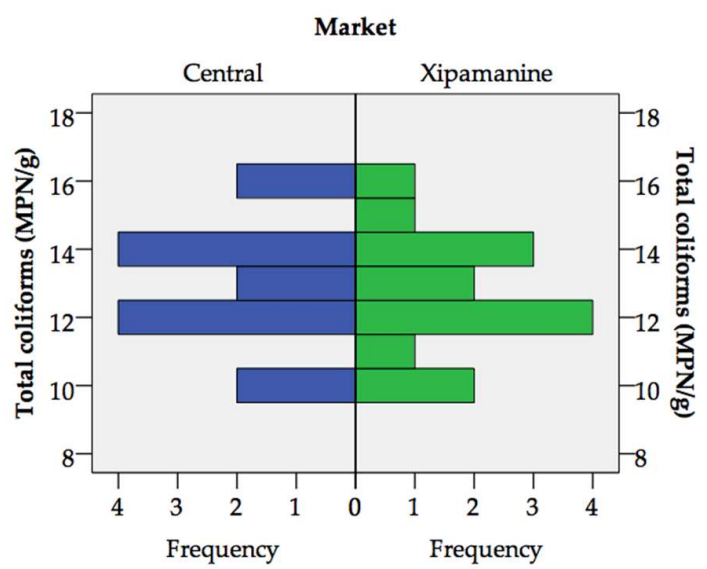

(b)

Figure 3. The level of total coliforms in lettuces from: (a) The three markets (p-value $<0.001)$; (b) only Central and Xipamanine ( $\mathrm{p}$-value $=0.701)$.

The samples from the Central and Xipamanine markets present total coliform profiles significantly similar (Figure 3b). Their distribution is normal, two-tailed, with very close interquartile ranges and the highest abundance of $12 \mathrm{MPN} / \mathrm{g}$ and $14 \mathrm{MPN} / \mathrm{g}$. This is certainly due to some similarities in handling features such as tap water washing and mixing the lettuces with other foods.

Regarding the washing water source, only 9 samples out of 42 used well water (Figure 4a). The samples washed with well water were the most contaminated ( $\mathrm{p}$-value $<0.001$ ), with an average load of $17.78 \pm 2.728 \mathrm{MPN} / \mathrm{g}$, against $13.52 \pm 2.252 \mathrm{MPN} / \mathrm{g}$ from the tap water washed samples.

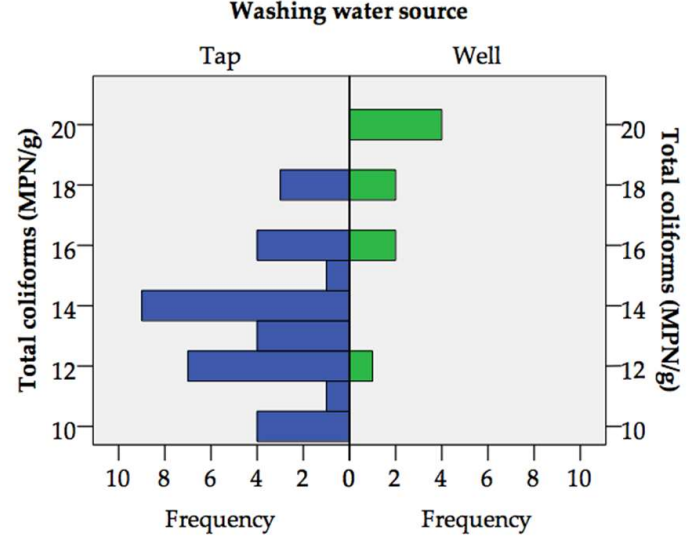

(a)

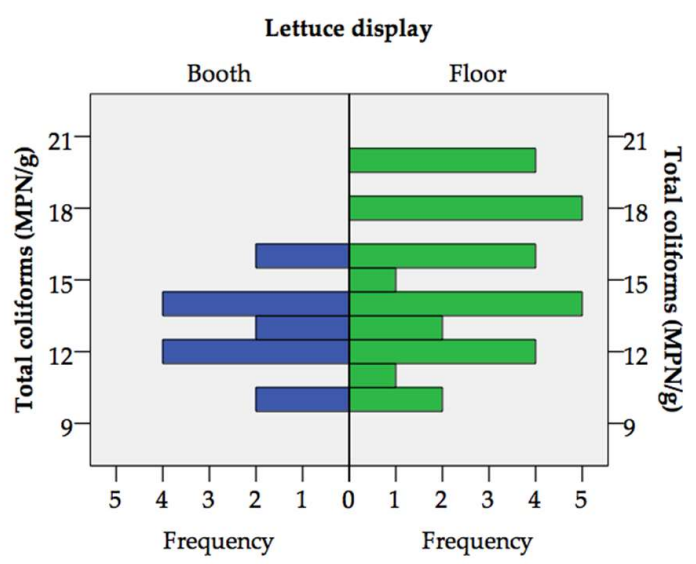

(b)

Figure 4. The level of total coliforms in lettuces considering: (a) The washing process; (b) Where the lettuce was displayed for sale.

The distribution was also different. The tap water exhibits a two-tailed distribution with predominance of values around $14 \mathrm{MPN} / \mathrm{g}$, while the tap water is one-tailed with notable negative skewness (-1.268), predominating the most heavily contaminated samples, with around $20 \mathrm{MPN} / \mathrm{g}$. These observations suggest that washing lettuce with well water is associated higher total coliform contamination than when tap water is used.

The Figure $4 \mathrm{~b}$ shows the total coliform levels considering how the lettuce was displayed for sale. The distribution of the levels was normal lettuce sold in booths and on the floor, with a wider range for the latter (28 samples). The differences were significant according to a Mann-Whitney test 
( $\mathrm{p}=0.023)$, and the samples sold in booths presented a lower average total coliform load $(13 \pm 1.84$ $\mathrm{MPN} / \mathrm{g})$ compared to the samples sold on the floor $(15.14 \pm 3.124 \mathrm{MPN} / \mathrm{g})$. Thus, this comparison also helps to distinguish the samples from the Central market and the others, as the former only used booths and the others sold all the lettuces on the floor, as Table $\mathbf{1}$ showed.

One-third of the samples were displayed together with other products (Figure 5a). This appeared to be related to the sellers themselves rather than the market conditions, as Table $\mathbf{1}$ showed. The differences in coliform loads between the lettuces sold with or without contact with different commodities were not significant $(p=0.093)$, possibly because the handling itself rather than the nature of the products.

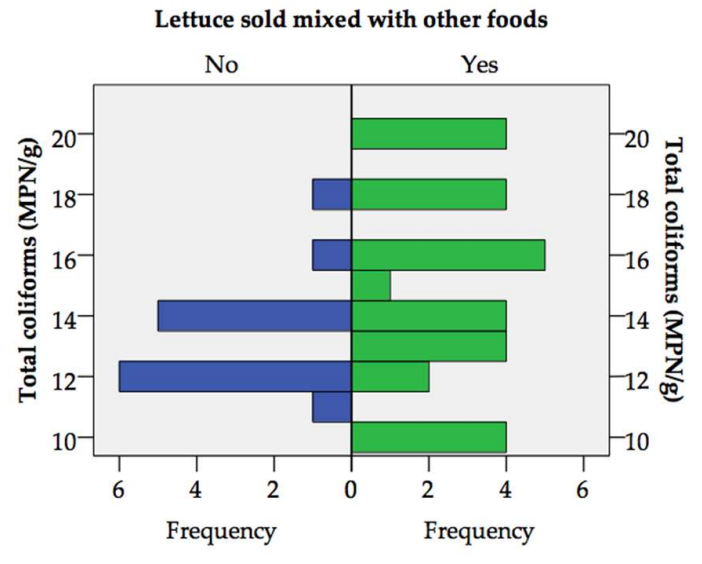

(a)

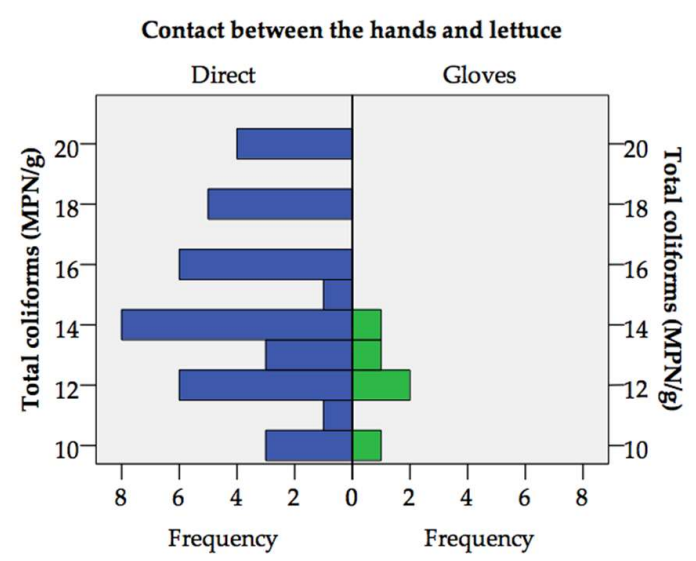

(b)

Figure 5. The level of total coliforms in lettuces considering: (a) If the lettuce was sold mixed with other foods; (b) If the lettuce was handled with gloves.

The lettuce mixed with other foods showed a wider range of contamination, and a lower skewness (0.064 against 1.190 from the non-mixed counterpart). It means it has abundance of the lowest values, while the other distribution is closer to normal. From this observation, not mixing lettuce with other foods is probably the best option to get less samples contaminated, although the differences were not significant at $\alpha=0.05$.

Only 5 sellers handled the lettuce with gloves (Figure 5b). The difference in contamination was not significant $(p=0.069)$ between the samples handled with or without gloves but the subgroup with gloves might not have been representative $(n<8)$ for a proper statistical analysis. Still, it is possible to see that all coliform loads when gloves were used (mean $=12.2 \pm 1.483 \mathrm{MPN} / \mathrm{g}$ ) are considerably low if compared with the distribution where gloves were not used (mean $=14.73 \pm 2.95$ $\mathrm{MPN} / \mathrm{g}$ ). It is necessary to get a larger sample subset in which the lettuce was handled with gloves but so far this practice seems to be associated with lower total coliform contamination.

Since gloves sellers from the Central Market used gloves, it is a good idea to analyze the differences in contamination only in this market. Indeed, the differences are not significant $(p=0.24)$ according to a Mann-Whitney test for independent samples. Thus, the difference found in the entire sample might have come from any factor causing the differences between the markets. Thus, the gloves did not seem to have a major impact on the level of total coliforms in the sample.

\subsubsection{Fecal coliforms}

All samples showed the presence of fecal coliforms. The levels ranged from $10 \mathrm{MPN} / \mathrm{g}$ to 18 $\mathrm{MPN} / \mathrm{g}$. According to a Kolmogorov-Smirnov test, the distribution was normal ( $\mathrm{p}=0.527)$, with a mean of $13.9 \pm 2.139 \mathrm{MPN} / \mathrm{g}$ (Figure 6). The confidence interval was 13.24 MPN/g to $14.57 \mathrm{MPN} / \mathrm{g}$. 


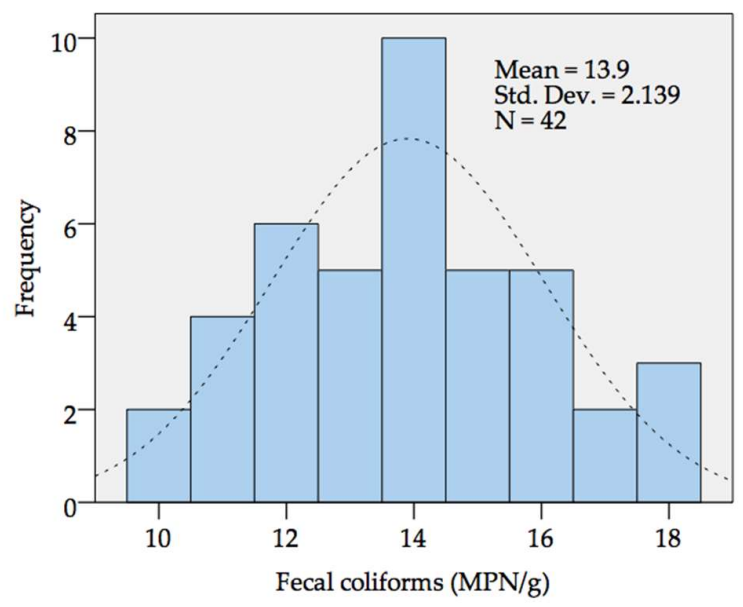

Figure 6. Levels of fecal coliforms detected in lettuce from Maputo City markets.

The levels of fecal coliforms were significantly different for the distinct markets (Figure 7), according to a Kruskal-Wallis test $(\mathrm{p}<0.001)$. Xiquelene market presented the highest average level $(15.57 \pm 1.604 \mathrm{MPN} / \mathrm{g})$, followed by Xipamanine $(13.57 \pm 1.222 \mathrm{MPN} / \mathrm{g})$ and central $(12.57 \pm 2.311$ $\mathrm{MPN} / \mathrm{g})$.

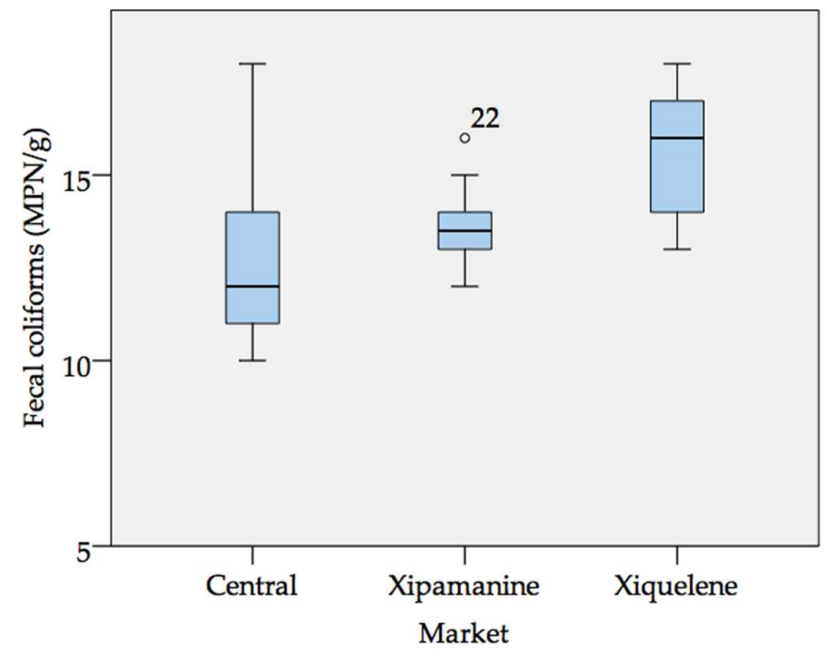

Figure 7. Comparison of levels of fecal coliforms in lettuces between the markets ( $p$-value $<0.001)$.

Figure 8a displays the relationship between the water source and the level of fecal coliforms. The differences were significant $(\mathrm{p}=0.004)$, according to a Mann-Whitney test. The samples washed with tap water had a lower presented a lower average level of contamination $(13.42 \pm 2 \mathrm{MPN} / \mathrm{g})$ if compared with the ones washed with well water $(15.67 \pm 1.732 \mathrm{MPN} / \mathrm{g})$. 


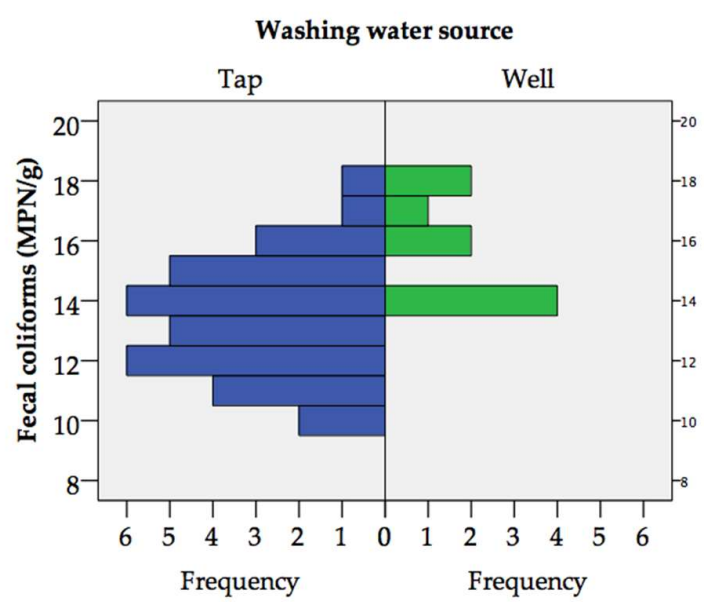

(a)

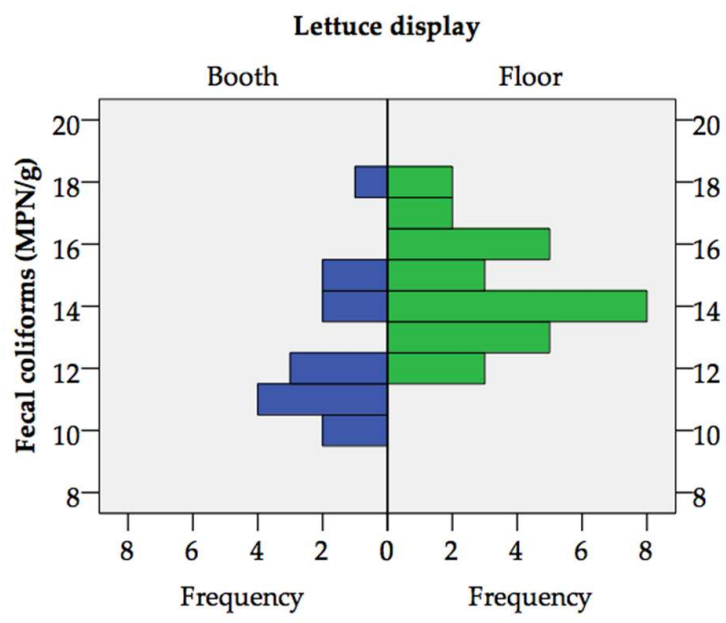

(b)

Figure 8. The level of fecal coliforms in lettuces considering: (a) The washing process; (b) Where the lettuce was displayed for sale.

Figure $8 \mathrm{~b}$ summarizes how the display of lettuce in booth or floor affected the levels of fecal coliforms. A Mann-Whitney test showed significant differences $(p=0.003)$. Lettuce displayed on the floor presented a higher average level of fecal coliforms $(14.57 \pm 1.731 \mathrm{MPN} / \mathrm{g})$ in relation to the lettuce in booths $(12.57 \pm 2.311 \mathrm{MPN} / \mathrm{g})$.

Regarding if the lettuce was or not mixed with other products (Figure 9a), the differences in levels of fecal coliforms were not significant, according to a Mann-Whitney test $(p=0.960)$. The mean was $13.93 \pm 1.979 \mathrm{MPN} / \mathrm{g}$ for non-mixed samples and $13.89 \pm 2.250$ for the mixed. This observation indicates that the mixture with other products had no impact on the fecal coliform level in lettuce.

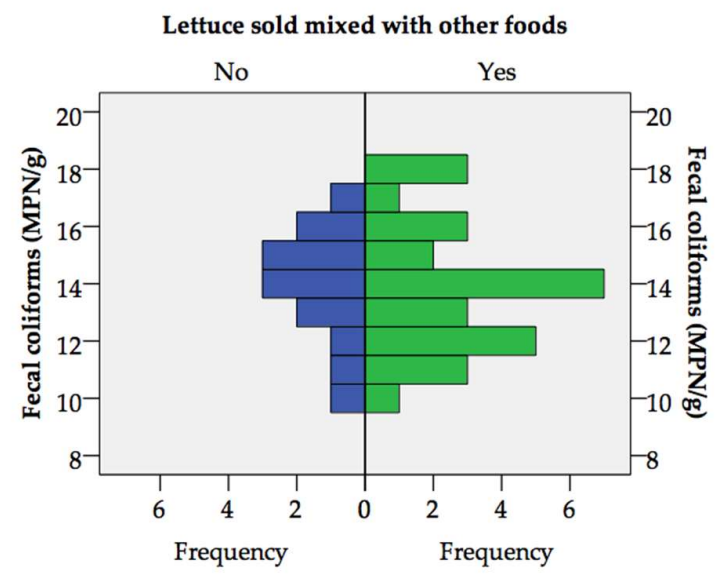

(a)

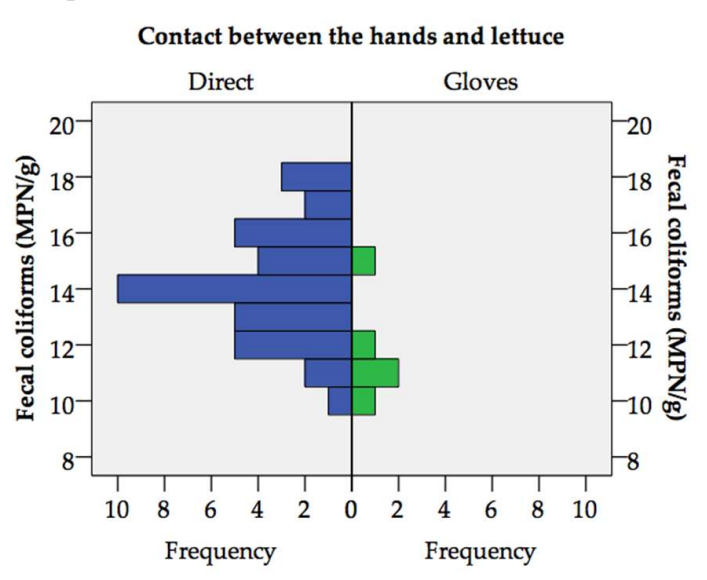

(b)

Figure 9. The level of fecal coliforms in lettuces considering: (a) If the lettuce was sold mixed with other foods; (b) If the lettuce was handled with gloves.

The use of gloves probably had an impact on the fecal coliform load (Figure 9b), as a Mann-Whitney test resulted in $\mathrm{p}=0.017$. However, only 5 samples were handled with gloves, meaning that it might not have been representative. Anyway, lettuce handled without gloves showed the highest average level of fecal coliforms (14.19 $\pm 2.025 \mathrm{MPN} / \mathrm{g})$ if compared to its counterpart $(11.8 \pm 1.924 \mathrm{MPN} / \mathrm{g})$. The confidence level was $11.13 \mathrm{MPN} / \mathrm{g}$ to $12.92 \mathrm{MPN} / \mathrm{g}$. Considering only the Central Market, the levels of fecal coliform were not significantly different $(\mathrm{p}=$ 0.438), according to an independent samples Mann-Whitney $U$ test. Thus, the difference verified in 
the entire sample is again related to certain peculiarities of the Central Market. The gloves probably did not affect also the levels of fecal coliforms.

\subsubsection{E. coli}

All samples had E. coli (Figure 10). The levels of E. coli ranged from $5 \mathrm{MPN} / \mathrm{g}$ to $18 \mathrm{MPN} / \mathrm{g}$. A Kolmogorov-Smirnov test confirms that levels of $E$. coli showed a normal distribution with an average of $12.02 \pm 2.88 \mathrm{MPN} / \mathrm{g}(\mathrm{p}=0.212)$. The confidence interval was between $11.13 \mathrm{MPN} / \mathrm{g}$ and 12.92 $\mathrm{MPN} / \mathrm{g}$.

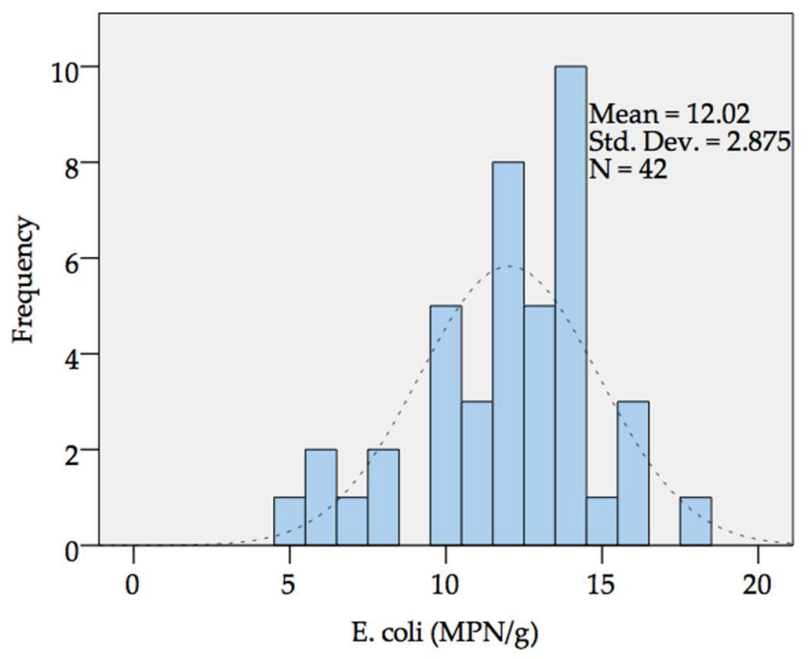

Figure 10. Levels of E. coli detected in lettuce from Maputo City markets.

Levels of E. coli contamination were significantly distinct $(\mathrm{p}<0.001)$ for the different markets (Figure 11), based on the results of a Kruskal-Wallis test. The highest average level was found in Xiquelene market $(14.07 \pm 1.73 \mathrm{MPN} / \mathrm{g})$, followed by Xipamanine $(12 \pm 1.519 \mathrm{MPN} / \mathrm{g})$ and Central (10 $\pm 3.442 \mathrm{MPN} / \mathrm{g})$.

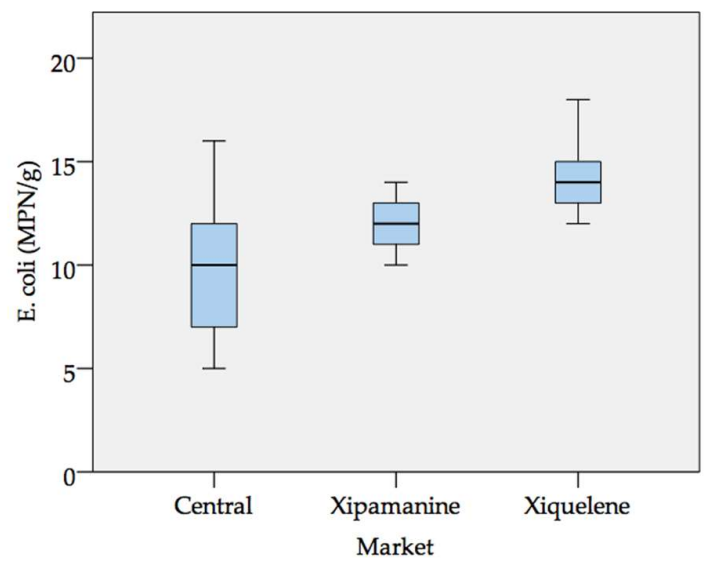

Figure 11. The level of E. coli in lettuces from the markets (p-value <0.001).

The water source appeared to have an impact on E. coli contamination (Figure 12a), according to a Mann-Whitney test $(\mathrm{p}=0.003)$. The level of $E$. coli was higher in samples washed with well water $(14.44 \pm 1.014 \mathrm{MPN} / \mathrm{g})$ than tap water $(11.36 \pm 2.87 \mathrm{MPN} / \mathrm{g})$.

The Figure $12 \mathrm{~b}$ shows if the display in booths or on the floor affected the level of E. coli. A mann-Whitney test indicated that their differences are significant $(p=0.001)$. The lettuce sold in booths had a lower average level of E. coli $(10 \pm 3.442 \mathrm{MPN} / \mathrm{g})$ when compared to lettuce sold on the floor (13.04 $\pm 1.915 \mathrm{MPN} / \mathrm{g})$. 


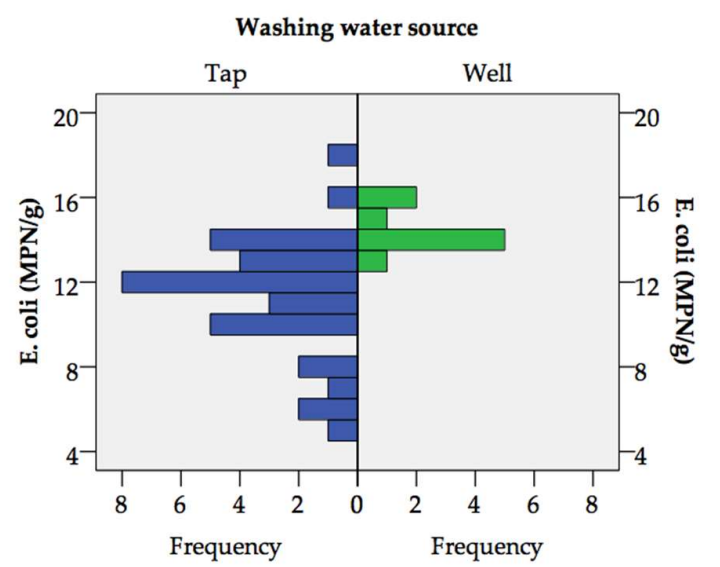

(a)

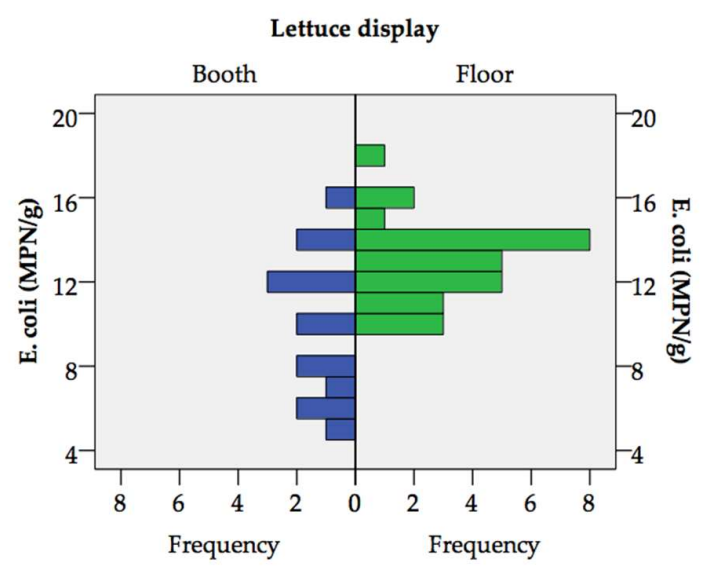

(b)

Figure 12. The level of total coliforms in lettuces considering: (a) The washing process; (b) Where the lettuce was displayed for sale.

The following observation was focused on the E. coli load in lettuce sold when mixed with other products or in isolation (Figure 13a). The difference was significant $(p<0.001)$ for a Mann-Whitney test. The samples mixed had higher average E. coli load $(13.11 \pm 2.266 \mathrm{MPN} / \mathrm{g})$ in relation to the non-mixed $(9.86 \pm 2.797 \mathrm{MPN} / \mathrm{g})$.

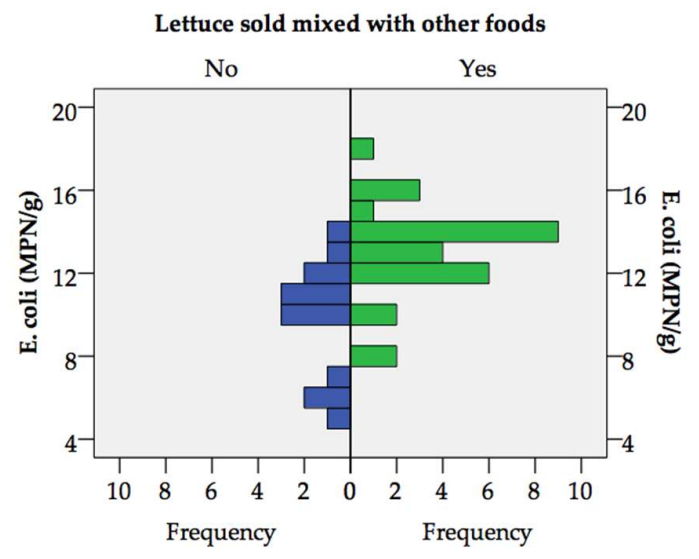

(a)

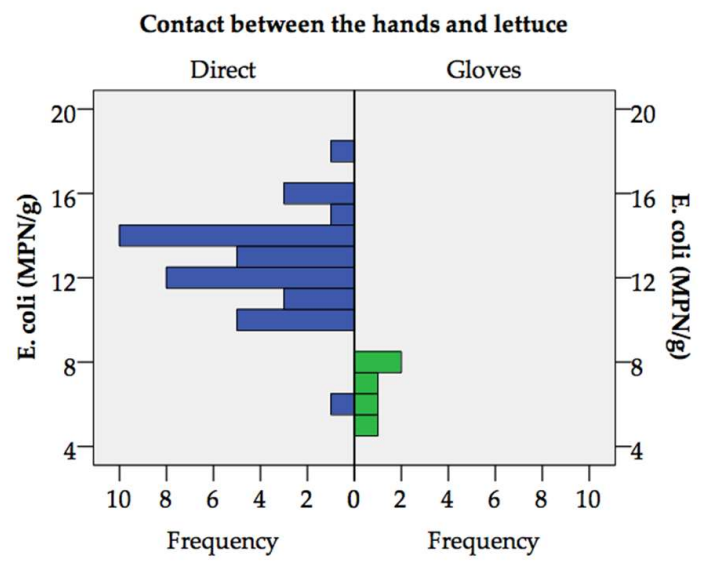

(b)

Figure 13. The level of total coliforms in lettuces considering: (a) If the lettuce was sold mixed with other foods; (b) If the lettuce was handled with gloves.

The last analysis was focused on the influence of handling the lettuce with gloves on levels of $E$. coli (Figure 13b). A Mann-Whitney test showed significant differences ( $p<0.001$ ), but again only 5 samples were treated with gloves. This sample showed the lowest average level of contamination $(6.8 \pm 1.304 \mathrm{MPN} / \mathrm{g})$. Samples handled without the gloves had an average level of $12.73 \pm 2.219$ $\mathrm{MPN} / \mathrm{g}$. For E. coli, significant differences were found even within the subsample from the Central Market ( $p=0.007)$, according to a Mann-Whitney $U$ test for independent samples. Thus, gloves apparently had a major impact on the level of E. coli among the samples.

Table 2 shows the differences in levels of $E$. coli between the samples handled with and without gloves. The samples treated with gloves presented the lowest average level, and a narrower range of values. Yet, it is important to notice that this subsample is poorly representative (14 lettuce heads), because the Central Market has 367 occupied booths, many used for fresh cut vegetables and fruits [11].

Table 2. Levels of E. coli in the Central Market for the samples treated with and without gloves. 


\begin{tabular}{cccccc}
\hline \multirow{2}{*}{ Contact between the hands and lettuce } & $\mathrm{n}$ & \multicolumn{4}{c}{ Level of E. coli (MPN/g) } \\
\cline { 3 - 6 } & 9 & 11.78 & 2.906 & 6 & 16 \\
\hline Direct & 5 & 6.80 & 1.304 & 5 & 8 \\
Gloves & 14 & 10.00 & 3.442 & 5 & 16 \\
\hline Total & & & &
\end{tabular}

\section{Discussion}

\subsection{Overall coliform levels}

The first thing to notice is that all samples were contaminated with total, fecal coliforms and $E$. coli, none in less than $5 \mathrm{MPN} / \mathrm{g}$. Thus, human or animal fecal contaminants entered the chain of production, and handling features were not effective enough to fully eliminate such organisms. Yet, all levels seem within the satisfactory range, even for ready-to-eat foods (with no need of washing), described by Gilbert, et al. [12] as less than $20 \mathrm{MPN} / \mathrm{g}$ for E. coli. Macaza [7] found some non-satisfactory results in 6 out of 10 of ready-to-eat foods containing some raw ingredients, collected in markets from Nampula City. However, the author did not explain which were the ingredients, the respective quantities, preparation and handling for sale. If the food had ingredients from different origins, and each handled in a particular way before the preparation, there were perhaps many more pathways from which the contamination took place if compared to the "straight forward" cultivation and harvest of lettuce. Thus, the report in Nampula shows evidence of food more heavily contaminated if compared with the current study but its unclear description of the dishes makes it difficult to compare both results.

The market had differences in the levels of contamination. The Central and Xipamanine markets presented considerably similar levels of total coliforms, but Xiquelene had a higher level. Regarding fecal coliforms and E. coli, Xiquelene still exhibited the highest levels, but the other two also had differences: the Central market had the lowest levels, followed by Xipamanine. These differences are likely related to the level of quality control in the markets, as a reflection of the government's intervention and level of urbanization. The City Council directly manages the Central market [9] and it is located at the city's most developed and commercially active area (the downtown). As one moves from this area, first finds Xipamanine market in a "slum" area, and then Xiquelene, in a suburban zone, which less control of the government.

There are other microbiological studies on lettuce from markets, but not from Mozambique. Two were performed in Brazil $[13,14]$ and used the same method as the current study (multiple tubes). There is actually one more, by Varallo, et al. [15] , but this one will not be discussed because the authors quantified the bacteria in the water used to wash the lettuce, not really on the vegetable itself. Amoah, et al. [16] analyzed and Amponsah-Doku [17] the contamination of lettuce market samples in cities from Ghana. None of these studies quantified E. coli, but the inclusion of this microorganism would have been better because several guidelines recommend it $[12,18,19]$, rather than total and fecal coliforms in general, to evaluate the quality of fruits and vegetables. Yet, the Brazilian studies were effectively carried out based on the Resolution RDC no. 12 (January $2^{\text {nd }}, 2001$ ) of the Brazilian National Agency for Health Surveillance (ANVISA) [20]. Amoah, et al. [16] and Amponsah-Doku [17] did not include E. coli but they used the guideline from The International Commission on Microbiological Specifications for Foods (ICMSF) [21], and studied other indicators of contamination, including helminthes and pesticides.

Pereira and Bezerra [14] estimated the most probable number per gram of total and fecal coliforms from two markets in Parintins city, in Amazonas. They collected samples in two subsequent weeks and analyzed separately. Comparing to the current study, they found higher average levels of both total (93 MPN/g) and fecal (29 MPN/g) in the first week. In the second, average fecal coliform level was even higher ( $35 \mathrm{MPN} / \mathrm{g}$ ) but for the total coliform the level (15 MPN/g) was within the current study's confidence interval (13.53-15.34 MPN/g). These authors considered their findings as acceptable for the Brazilian Standard [14], but the presence of fecal coliforms indicated 
poor hygiene practices. Methodological limitations rendered the Brazilian study impractical to draw comparisons. It is also important to notice that they collected only four samples, one per market in two subsequent weeks. Their sample size does not seem representative, though they also did not specify how large the markets were.

Barbosa, et al. [13] analyzed samples from five markets from the city of João Pessoa, in Pernambuco. They found generally higher average levels of total coliforms (all above $2400 \mathrm{MPN} / \mathrm{g}$ ) in markets if compared to Pereira and Bezerra [14] , and 20-fold over the limits set by ANVISA [20] (100 MPN/g). On the other hand, the average level for fecal coliforms was between $17 \mathrm{MPN} / \mathrm{g}$ and 34 $\mathrm{MPN} / \mathrm{g}$, not very different for the range found in the other Brazilian study, yet considerably high for the overall findings in the current study. Extremely high coliform levels found by Barbosa mean that their samples were heavily contaminated and they pose a risk for the public health. Perhaps the source of contamination was not in the markets themselves because all of them exhibited the same magnitude of contamination. They should also consider the non-fecal source of contamination, as for over $2000 \mathrm{MPN} / \mathrm{g}$ only less than $40 \mathrm{MPN} / \mathrm{g}$ were of fecal origin.

Amoah, et al. [16] found extremely high levels of fecal coliforms (none below 4,000 MPN/g) in markets from the cities of Accra, Kumasi and Tamale. The eggs of Ascaris, Ancylostmoma, Schistosoma and Trichuris in the lettuce samples conformed their suboptimal sanitary conditions. For Amponsah-Doku [17], the minimum level of fecal coliforms was 3,900 MPN/g, in Kumasi. These values are considerably higher than ICMSF recommendation (1,000 MPN/g). Amoah, et al. [16] attributed the contamination to the polluted water used for irrigation, manure run-off from the field, and poor hygiene practices such as the continuous reuse of the water to wash the lettuce for an entire day, making the lettuce increasingly dirtier. The authors said the ultimate cause is the intensive production, lack of proper food safety management or enforcement of the available policies. Lack of proper intervention explains why in Maputo the remoteness from the city center is associated with higher levels of contamination. The more urbanized the area, the more effective management of safety policies.

These comparisons suggest that samples from Maputo markets were safer to consume than the ones from the markets in Nampula, the Brazilian and Ghanaian cities. It is remarkable that even including some cooked food, samples from Nampula still showed some unsatisfactory results, deductively above the levels of the raw lettuce from Maputo. If the contamination was still high in Nampula after cooking, it was likely caused or increased at a late stage, possibly by pollutant agents such as dust, aerosols, insects or poorly hygienic handling tools or practices [22-24].

\subsection{Handling features and levels of coliforms}

The first handling feature analyzed was the source of water used to use the lettuce. The samples washed from well water were consistently more heavily contaminated than the ones washed with well water, disregarding the group of coliforms analyzed $(p<0.05)$. It implies that the water quality had an impact on the contamination, although all samples were within the satisfactory range for consumption. The differences certainly occurred because the tap water from Maputo City is treated with chemicals such as chlorine [25]. Underground water is prone to contamination and it can have high levels of coliforms if not treated [26,27]. According to Gil, et al. [28] and Amoah, et al. [29], non-sanitized water can transfer microorganisms to vegetables, including potential pathogens.

Concerning the display, the contamination was higher for the lettuce sold on the floor in relation to samples from booths. This difference certainly occurred because the products on the floor were more exposed to air pollution, insects, and other factors associated with their environment. In their study of human pathogens in street vended fruit juice in India, Lewis, et al. [30] mentioned other potential causes of contamination, applicable to the markets in Maputo City: the location by the side of a busy road with heavy traffic, overcrowded, and near waste disposal. A better infrastructure prevents the influence of such agents and it explains why the levels of contamination were higher in Xipamanine and Xiquelene markets (where all lettuce was sold on the floor) in relation to Central (with all lettuce sold in booths). 
Cross-contamination was also considered. Mann-Whitney tests showed no significant impact of mixing products with lettuce on the levels of total $(p=0.093)$ and fecal $(p=0.960)$ coliforms, but it was significant for E. coli $(\mathrm{p}<0.001)$. Lettuce might have potentially acquired food borne pathogens from other products when sold mixed. If other products came from different sources, they were likely subjected to distinct patterns or pathways of contamination [31,32], bringing new additions to the mix. By the same logic, a mixture of products can result in a varied range of microenvironments with different nutritional composition, water activity or other factors, offering the microorganism the possibility to better survive in one or another condition. Even if the products are not in direct contact, one can expect the handlers to frequently touch the different commodities, spreading the coliforms. According to Amponsah-Doku [17], the situation can be even worse. In markets from Kumasi (Ghana), it was common for sellers to use the same water to wash all vegetables and their hands, without changing for long periods.

This analysis ended with the comparison of levels of coliforms for the lettuce treated with and without gloves. Only 5 people used gloves, all in the Central Market. The gloves did not reduce significantly the extent of total and fecal coliform contamination. This is perhaps the gloves protected the hands rather than the vegetables themselves, i.e., the handlers might have kept their hands clean but the main problem during the sales is more likely to be cross contamination when as the sellers touch the cabbages or other products, the surfaces or other objects entering in contact with the vegetables [8,17]. E. coli seemed to be affected by the use of gloves, but the fact that only 5 samples were handled with gloves, in the same market, calls for further analyses. It is open to many possibilities. These sellers could be related, either by having the same supplier, sharing their material, or many other variables worth analyzing in the future. Anyway, the differences they made by wearing gloves can be taken as an example because and it should be encouraged.

\section{Conclusions}

All samples from the three markets of Maputo were contaminated with total, fecal coliforms and E. coli. Though it indicates poor hygiene, all levels were within the satisfactory range for guidelines from ICMSF, ANVISA and others. Indeed, they were lower than levels found in other tropical countries. Central Market had the safest lettuce handling facilities, and it resulted in the lowest levels of all groups of coliforms analyzed. The biggest difference between this market and the others was the exclusive use of running water only to wash the lettuce, instead of underground well, and use of booths to exhibit the lettuce, instead of putting it on the floor. Cross contamination had a minor impact, but it allowed a considerable increase of E. coli levels. The best idea is to keep the vegetable separated if possible. The use of gloves also had a minor impact, although it requires further analysis with a representative sample. Thus, the lettuce from the markets in Maputo City seem safe for consumption but the consumers shall wash the lettuce because it is often eaten raw, and if fecal coliforms made into the vegetables, potential pathogens might as well. These results could be well subsidized with data on Salmonella, other Enterobacteriaceae, so as helminthes.

Author Contributions: Conceptualization, Luís Gazeta and Edgar Cambaza; Methodology, Luís Gazeta; Formal Analysis, Luís Gazeta \& Edgar Cambaza; Writing-Original Draft Preparation, Edgar Cambaza; Writing-Review \& Editing, Elda Anapakala; Supervision, Shigenobu Koseki and Shuso Kawamura".

Acknowledgments: Department of Microbiology in the Mozambican National Laboratory of Water and Food Hygiene and Analysis (LNHAA), Maria Tauzene and Maria Isabel Isabel Amado, for the precious suggestions.

Conflicts of Interest: The authors declare no conflict of interest.

\section{References}

1. Sitoe, T.A. Diversificação produtiva e de atividades de geração de renda: Uma análise da produção hortícola no cinturão verde da cidade de maputo-região sul de moçambique. 2010.

2. Ribeiro, J.E.M.M.; Rulkens, A.; Menete, M.Z. Estudo do efeito da aplicação combinada do bagaço da mafurra e da ureia na cultura de alface (lactura sativa l); Universidade Eduardo Mondlane: Maputo, 1996. 
3. Sitoe, T.A. A extensão agrícola e as" escolas na machamba do camponês" em moçambique: O caso da produção hortícola nas zonas verdes da cidade de maputo. Revista Brasileira Multidisciplinar 2010, 13, 50-69.

4. Commission, C.A. Code of hygienic practice for fresh fruits and vegetables (cac/rcp 53-2003). Rome: FAO/OMS 2003.

5. Muchimbane, A.B.D.A. Estudo dos indicadores de contaminação das águas subterrâneas por sistemas de saneamento in situ distrito urbano 4, cidade de maputo-moçambique. Universidade de São Paulo.

6. Ackers, M.-L.; Mahon, B.E.; Leahy, E.; Goode, B.; Damrow, T.; Hayes, P.S.; Bibb, W.F.; Rice, D.H.; Barrett, T.J.; Hutwagner, L., et al. An outbreak of escherichia coli o157:H7 infections associated with leaf lettuce consumption. The Journal of Infectious Diseases 1998, 177, 1588-1593.

7. Macaza, B.S. Avaliação da qualidade e segurança microbiológica de alimentos de rua vendidos nos mercados municipais da cidade de nampula, moçambique. 2017.

8. Alves, T.M.d.B. Bases para o planeamento de estratégias de educação sanitária alimentar em Moçambique (confecção, venda e consumo de alimentos no espaço público). Instituto Superior de Ciências da Saúde Egas Moniz, 2014.

9. Guia do consumo de peixe para mulheres, crianças e famílias. In Eating Well with Canada's Food Guide, Toronto Public Health: Toronto.

10. McCrady, M.H. The numerical interpretation of fermentation-tube results. The Journal of Infectious Diseases 1915, 183-212.

11. CMM. Perfil estatístico do município de maputo, 2010. Sócio-Económicas, D.d.E.e.E., Ed. Conselho Municipal de Maputo: Maputo, 2010.

12. Gilbert, R.; Donovan, T.; Little, C.; Nye, K.; Ribeiro, C.; Richards, J.; Roberts, D.; Bolton, F. Guidelines for the microbiological quality of some ready-to-eat foods sampled at the point of sale. Phls advisory committee for food and dairy products. Communicable disease and public health 2000, 3, 163-167.

13. Alves, G.S.; de Brito, H.C.; Lemos, E.M.; Vasconcelos, O.d.O.; Alves, G.S. Análise microbiológica de alface (lactuca sativa var. Crispa) de diferentes pontos de comércio da cidade de joão pessoa-pb. Revista Verde de Agroecologia e Desenvolvimento Sustentável 2013, 8, 09-11.

14. Pereira, A.T.d.S.; Bezerra, C.C. Avaliação microbiológica da lactuca sativa (alface) comercializada nas feiras da cidade de parintins-am; Universidade do Estado do Amazonas: Manaus, 2017.

15. Varallo, A.C.T.; de Souza, J.M.; Rezende, S.S.R.; Souza, C.F. Avaliação da qualidade sanitária da alface (lactuca sativa, 1.) irrigada com água de reúso comparada com amostras comercializadas/evaluation of sanitary quality of lettuce (lactuca sativa, 1.) irrigated with reused water in comparison with commercialized lettuce. Revista Ambiente \& Água 2011, 6, 295.

16. Amoah, P.; Drechsel, P.; Abaidoo, R.C.; Ntow, W.J. Pesticide and pathogen contamination of vegetables in ghana's urban markets. Arch Environ Contam Toxicol 2006, 50, 1-6.

17. Amponsah-Doku, F. Bacterial contamination of lettuce and associated risk factors at production sites, markets, and street food restaurants in urban and peri-urban kumasi. Kwame Nkrumah University of Science and Technology, 2006.

18. Agency, H.P. Guidelines for assessing the microbiological safety of ready-to-eat foods placed on the market. Health Protection Agency: London, 2009; p 34.

19. FSAI. Guidelines for the interpretation of results of microbiological testing of ready-to-eat foods placed on the market. Food Safety Authority of Ireland: Dublin, 2016; p 48.

20. ANVISA. Regulamento técnico sobre padrões microbiológicos para alimentos; Diretoria Colegiada da Agência Nacional de Vigilância Sanitária: Brasilia, 2001; p 45. 
21. Schothorst, M. Establishment of microbiological safety criteria for foods in international trade. International commission on microbiological specifications for foods. World Health Stat Q 1997, 50, 119-123.

22. Rosas, I.; Salinas, E.; Yela, A.; Calva, E.; Eslava, C.; Cravioto, A. Escherichia coli in settled-dust and air samples collected in residential environments in mexico city. Applied and environmental microbiology 1997, 63, 4093-4095.

23. Geldreich, E.E.; Kenner, B.; Kabler, P. Occurrence of coliforms, fecal coliforms, and streptococci on vegetation and insects. Applied microbiology 1964, 12, 63-69.

24. Lembke, L.L.; Kniseley, R.N. Coliforms in aerosols generated by a municipal solid waste recovery system. Applied and environmental microbiology 1980, 40, 888-891.

25. Arnal, J.; García-Fayos, B.; Sancho, M.; Verdú, G.; Lora, J. Design and installation of a decentralized drinking water system based on ultrafiltration in mozambique. Desalination 2010, 250, 613-617.

26. de Freitas, M.B.; de Almeida, L.M. Qualidade da água subterrânea e sazonalidade de organismos coliformes em áreas densamente povoadas com saneamento básico precário. Águas Subterrâneas 1998.

27. Freitas, M.B.d.; Brilhante, O.M.; Almeida, L.M.d. Importância da análise de água para a saúde pública em duas regiões do estado do rio de janeiro: Enfoque para coliformes fecais, nitrato e alumínio. Cadernos de Saúde Pública 2001, 17, 651-660.

28. Gil, M.I.; Selma, M.V.; Lopez-Galvez, F.; Allende, A. Fresh-cut product sanitation and wash water disinfection: Problems and solutions. International journal of food microbiology 2009, 134, 37-45.

29. Amoah, P.; Drechsel, P.; Henseler, M.; Abaidoo, R.C. Irrigated urban vegetable production in ghana: Microbiological contamination in farms and markets and associated consumer risk groups. $J$ Water Health 2007, $5,455-466$

30. Lewis, J.E.; Thompson, P.; Rao, B.; Kalavati, C.; Rajanna, B. Human bacteria in street vended fruit juices: A case study of visakhapatnam city, india. Internet Journal of Food Safety 2006, 8, 35-38.

31. Reij, M.W.; Den Aantrekker, E.D. Recontamination as a source of pathogens in processed foods. International journal of food microbiology 2004, 91, 1-11.

32. Fenlon, D.; Wilson, J.; Donachie, W. The incidence and level of listeria monocytogenes contamination of food sources at primary production and initial processing. Journal of Applied Microbiology 1996, 81, 641-650. 